Published on Reviews in History (https://reviews.history.ac.uk)

\title{
Venetian Digital Resource Review
}

Review Number: 2140

Publish date: Thursday, 27 July, 2017

Editor: Reinhold C. Mueller

Alfredo Cosco

Date of Publication: 2016

Publisher: Università Ca' Foscari di Venezia

Publisher url: http://www.civesveneciarum.net/

Place of Publication: Venice

Editor: Alfredo Cosco

Linda Guzzetti

Reinhold C. Mueller

Date of Publication: 2016

Publisher: Università Ca' Foscari di Venezia

Publisher url: http://www.estimoveneziano1379.it/homepage

Place of Publication: Venice

Reviewer: Georg Christ

CIVES [3] and ESTIMO [4] are two databases providing a wealth of important data for the social and economic history of Venice in the late Middle Ages. Both are directed by Reinhold C. Mueller, professor emeritus at the Ca' Foscari University in Venice and edited and managed by Dr Alfredo Cosco. The type of information presented is pretty straightforward and it should therefore not be a problem for the Englishspeaking user that explanations are provided in Italian (one would also hope in any case that scholars interested in the subject would endeavour to learn it).

CIVES is a slender and well-designed database of all privileges of citizenship. The 'Credits' mention Annalisa Conterio, Andrea Mozzato and Stefano Piasentini as Mueller's collaborators. The database seems to have originated as a Filemaker database, which was subsequently made available online by Luigi Siciliano and then recently re-engineered (HTML5) by Alfredo Cosco. The data informed a thorough analysis of Venetian citizenship by Professor Mueller published in 2010.(1) Venice at the time granted citizenship of different types (de iure (originarius/factus privilegio), de gratia, ad honorem) and status (de intus, de extra/foris or both).(2) This typology is widely known and available, not least in the abovementioned book, but it might have been useful to reiterate some of these basics also in the 'help' section.

As the name CIVES indicates, this database collects privileges granted for Venetian citizenship but focuses on the cives (Lat. for citizens) in the more narrow sense, i.e. the common citizen without noble/patrician status. There are good reasons for this. Although the serrata was perhaps not as strict as sometimes assumed, admission to the patriciate was handled far more restrictively.(3) Most importantly, the cives, as some sort of middle class, although perhaps studied less, are essential to understand the Venetian economy and administration. While officially headed by patricians, on the more practical level the administration was run by cives clerks, often with juridical training. 
The bibliography contains a wealth of relevant literature, though this is naturally restricted to Venice.(4) The 'help' section is not so much an IT-technical help (which should hardly be necessary) but an explanation of the abbreviations and a most interesting and laudable source critical introduction to the data. It explains how the datasets were extracted from the primary sources giving a few examples of citizenship privileges transcribed in extenso. This cannot be commended enough. One of the most problematic features of databasegrounded analysis is that the link to the primary sources often gets somewhat lost in compilation. Yet it is crucial that the historian remains mindful of the extraction/compilation process and its potential shortcomings and constantly refers back to the original in order to test the robustness of statistical analysis. It might have been good to have a fully commented list of fields as provided for ESTIMO (see below). For dates it is noted that 1 January year XY does not denote 1st of January (when the administration did not officiate) but stands in if only the year of the privilege is known (probably because Filemaker date fields require a full date). I assume that dates are normalized to modern conventions, i.e. from anno ab incarnatione (more Veneto) to anno ab circumcisione domini although that is not specified. The normalisation of Latin names into Italian is effected in the field 'Nome italianizzato' while the 'Nome latino' retains the original diction of the primary source. The standard applied for this process of normalisation is not clearly defined (and to define such standards is admittedly difficult). Place names, in particular the names of confine i.e. parishes, are normalized according to Beltrami's Storia della popolazione (5) rather than E. Orlando et al.'s standard applied to the publication of the Redecima as in ESTIMO, see below note seven (which did not exist at the time).

What seems somewhat unsystematic are the (admittedly complicated) restrictions attached to the privileges (and which make rushed statistical exploration of privileges by status problematic). In the case of Abbas, David iudeus, for instance, the restriction is contained in the 'note' field: David can only enjoy his civis privileges in Negroponte (Euboea and, perhaps, by tacit agreement, the wider Eastern Mediterranean) but not, and that is probably at the heart of it, in Venice and its metropolitan area. On the card for Philippus et Nicolaus de Malerbis Benvegne, however, the restriction is contained in a special field ('Limitazioni del privilegio'): They are not allowed to trade with the Fondaco dei Tedeschi. The reason for the different treatment no doubt is that the case of David (not a Christian and not gaining citizenship in Venice) is a particular one and therefore treated differently. Civesveneciarum.net can be browsed as alphabetical list or more handily accessed through a search function - a simple one line search or a 'ricerca avanzata' by fields.

ESTIMO contains the data of a Venetian 'tax register' of early spring 1379 (taken before April). It is based on three substantially differing manuscripts from much later periods (16th, 17th and 18th centuries) and has been published before e.g. by Gino Luzzatto although in poor editions based solely on one manuscript and apparently with errors. The credits mention again A. Cosco, as webdesigner and webmaster, and Linda Guzzetti, who revised the data. The introductory section explains the history and the principles of the edition as well as the tax system. This list was not for the purpose of imposing 'regular' taxes but of extraordinary contributions under the form of forced state loans. The payer received a bond and usually twice yearly interest payments of 5 per cent. The actual units of assessment grouped in the list are not clear at first: the introduction speaks of 'ditta' (a technical term - not meaning firm). Looking through the very detailed and clear description of the fields/categories of the database it becomes clear that it denotes the taxed unit/taxpayer (Ital. contribuenti/tassati), both legal and natural persons (personelenti i e persone fisiche and giuridiche).

It makes sense to have a field (whether called 'ditta' or 'unita tassata' or whatever) where the names are rendered as given in the manuscripts, combined with two separate fields for given and family names in Italianised and normalized form (i.e. Giovanni rather than Zane, Zovanin etc.). This solution allows for the retaining of the original form while greatly enhancing the searchability of the data. How the names were Italianised and normalised is not quite clear. Were the standards proposed by the State Archive of Venice/Orlando et al. followed, as is explicitly the case for Venetian toponyms? (6) It would certainly make sense to do so in future projects. 
The search tab is functional, with sub-tabs for 'semplice' and 'avanzata' searches. The search results are clearly laid out in a handy list with buttons behind each entry leading to the complete dataset, opening in a separate window. There is also a tab 'statistiche' which provides overviews over the distribution of the assessed sums by sestiere ( sixth-part of the city) and contrada (parish).

Particularly useful is the export function (pdf, csv, Excel - the latter did not work on my machine but that does not matter as the export of data in csv [comma separated values] format worked fine), which greatly facilitates further treatment and analysis of the data. The data can also be copied to the clipboard by simple click on the respective button and the view can be personalised (number of rows, columns). The database can be browsed ('scorri'), where one also finds an (albeit rudimentary) map feature (it is understood that it would be very difficult to define the boundaries of parishes) yet, unfortunately, not the statistical features provided for search results. The appendix is most useful but there again (as it provides the total sums assessed per parish, part of the city and the entire city) statistical tools and a representation on a map would have been useful.

These two databases stand in their rigorous and robust efficiency in the best tradition of the Venetian school of medieval social and economic history. The particular value of the databases is that they do not provide a mere digitisation of archival material as is increasingly available through the project Divenire of the State Archives of Venice (Archivio di Stato di Venezia, ASVe) (7) but make processed data extracted from such sources available. One might, of course, have wished for an integration of these databases with Divenire. However, as web-based databases are in constant flux, one can understand why Mueller and his team went for a more cautious and reductionist approach avoiding all links except those between the two databases here reviewed (links from ESTIMO to novi cives in CIVES) in order to avoid the problem of changing architectures with subsequent breaking of links.

The databases are both processed data to inform research as well as repositories in support of concluded and published work. CIVES thus is the repository of data supporting Mueller's 2010 Immigrazione e cittadinanza - a procedure not only normal but indeed expected in the natural sciences in order to enhance the reproducibility of research findings. One might wish that this should be common practice in archive-based research too. Yet that is not the case. Such databases as the ones here reviewed are relatively rare. More common are two more radical solutions to archive related data management challenges: While archive based historians seem to favour an isolationist my-data-is-my castle approach, well-funded computer scientists, Google and some archives and libraries embrace total digitisation.

The former (and I do not exclude myself) keep their research data even after publication of resulting analytical work on their hard-drives. Some pretend to publish data online but do not take adequate care that they become and remain available. That is a pity (and in some cases at odds with funding regulations). The data might be helpful to other researchers and stimulate and foster new research which one individual could never undertake alone. The reasons why data is not shared vary: one problem is that most researchers do not collect and normalize data systematically; loose notes, digital or paper, are not easily transformed into a searchable database. Transcriptions might be unfinished or dodgy, extraction of data patchy etc. Yet another potent reason might be that historians suffer from a certain collective fear that someone might snatch findings combined with the unrealistic hope that one day they could 'do something' with this data.

All-encompassing, large scale projects by contrast might never see the light of the day or remain reduced to digitisation without extraction, normalisation, categorisation and analysis of data as this cannot be easily delegated to powerful algorithms and requires not only the historian's specialist skill and knowledge but also considerable courage to define structures, categories, ontologies, and standards in a somewhat hostile context of a post-structuralist and linguistically turned research and funding environment.

Against this backdrop the conversations initiated within the short introductory texts of these databases as well as in the above-mentioned projects Redecima/Condizioni di decima or the Rulers of Venice database (8) 
(co-edited and engineered by A. Mozzato, who is also part of the CIVES team), are hopefully the first steps towards a set of standards for the treatment of Venetian archival material. This again would be the precondition for deploying a meta-search engine integrating and giving access to a wider range of Venetianist databases. The Venetian state archives, the Biblioteca Nazionale Marciana and the Ca' Foscari University would be the natural partners in such an enterprise that would have to deal not only with the normalisation of different types of names but also the definition of useful categories for occupations, legal entities etc. A time line would enhance the summative analysis of diachronic databases such as CIVES or Rulers of Venice while descriptive/explorative statistical features and a GIS application (to represent data on maps historic or modern) would enhance databases furthermore. Yet for the moment we shall be thankful that two precious sets of data have been made accessible in a durable, easy and useful way. They are testament that it can and should be done, and should be an inspiration to others.

\section{Notes}

1. Reinhold C. Mueller, Immigrazione e cittadinanza nella Venezia medievale, Deputazione di Storia Patria per le Venezie, studi 1 (Venice, 2010).Back to (1)

2. <http://arielcaliban.org/VEcittadinanza.pdf [5]> [accessed 29 May 2017].Back to (2)

3. B. G. Kohl, 'The serrata of the Greater Council of Venice, 1282-1323: the documents', ed. R. C. Mueller, in Venice and the Veneto during the Renaissance: the Legacy of Benjamin Kohl, ed. M. Knapton, J. E. Law, and A. A. Smith (Florence, 2014; e-book: www.ebook.retimedievali.it [6]), pp. 3-34; S. Chojnacki, 'La formazione della nobilità dopo la serrata', in La formazione dello stato patrizio, ed. G. Arnaldi, (Rome, 1997), pp. 641-725 [Storia di Venezia, vol. 3]; cf. D. E. Queller, The Venetian Patriciate: Reality versus Myth (Urbana, IL, 1986).Back to (3)

4. See for citizenship in the wider Venetian maritime realm, R. C. Mueller, 'The status and economic activity of Jews in the Venetian Dominions', in Wirtshaftsgeschichte der mittelalterlichen Juden, ed. M. Toch, pp. 63-92 (Munich, 2008); Ph. Baroutsos, 'Privileges, legality and prejudice: the Jews of Corfu on the way to isolation', in «Interstizi»: Culture ebraico-cristiane a Venezia e nei suoi domini tra basso medioevo e prima epoca moderna, ed. by U. Israel, R. Juette and R. C. Mueller (Rome, 2010); ibid, 'Venetian pragmatism and Jewish subjects (fifteenth and sixteenth centuries)', Mediterranean Historical Review, 27, 2 (2012), 227-40; D. Jacoby, 'Venetian citizenship and nationality in the Eastern Mediterranean, 13th-15th Century', in Trading Empire: Rethinking Venetian Rule in the Eastern Mediterranean 1400-1700 - A Festschrift in Honour of Benjamin Arbel, ed. G. Christ (Leiden, in preparation); for a later period: L. A. Cecchini, and L. Pezzolo, 'Merchants and institutions in early-modern Venice', JEEH 2 (2012), 89-114. For the concept of citizenship in legalhistorical perspective, see the studies by J. Kirshner, for example, 'Between nature and culture: an opinion of Baldus of Perugia on Venetian citizenship as second nature', Journal of Medieval and Renaissance Studies, 9, 2 (1979), 179-208 (citied in Mueller's Immigration and Citizenship) and Marriage, Dowry, and Citizenship in Late Medieval and Renaissance Italy.Back to (4)

5. D. Beltrami, Storia della popolazione di Venezia dalla fine del secolo XVI alla caduta della repubblica (Padova 1954), tavola no. 1.Back to (5)

6. <http://www.archiviodistatovenezia.it/web/index.php?id=63 [7]> [accessed 29 May 2017].Back to (6)

7. <http://www.archiviodistatovenezia.it/divenire/collezione.htm?idColl=5250... [8] [accessed 29 May 2017]. Explanations <http://www.archiviodistatovenezia.it/web/index.php?id=214 [9]> [accessed 29 May 2017], on normalization of toponyms, dates and names: < http://www.archiviodistatovenezia.it/web/fileadmin/template/allegati/Utilia/criteri_di_normalizzazione.pdf [10] > [accessed 29 May 2017].Back to (7)

8. The Rulers of Venice, 1332-1524: Interpretations, Methods, Database, 2004-2017, ed. B. G. Kohl, A. Mozzato, and M. O'Connell <http://rulersofvenice.org/ [11]> [accessed 29 May 2017].Back to (8)

Source URL:https://reviews.history.ac.uk/review/2140

\section{Links}

[1] https://reviews.history.ac.uk/item/204245 
[2] https://reviews.history.ac.uk/item/204246 [3] http://www.civesveneciarum.net

[4] http://www.estimoveneziano1379.it/ [5] http://arielcaliban.org/VEcittadinanza.pdf

[6] http://www.ebook.retimedievali.it [7] http://www.archiviodistatovenezia.it/web/index.php?id=63

[8]

http://www.archiviodistatovenezia.it/divenire/collezione.htm?idColl=52507\&amp;\&amp;inTab=list\&amp;numPage

[9] http://www.archiviodistatovenezia.it/web/index.php?id=214

[10]

http://www.archiviodistatovenezia.it/web/fileadmin/template/allegati/Utilia/criteri_di_normalizzazione.pdf [11] http://rulersofvenice.org/ 